\title{
THE APPLYING OF THE METHOD OF VARATION OF PARAMETERS AND DIFFERENT CIRCUITS OF ANGULAR PARAMETERS TO SIMULATE THE BLADE OF THE COMPRESSOR
}

Spirintsev D.V., Dr.Ph

spirintsev@gmail.com, ORCID: 0000-0001-5728-6626

Naidysh A.V., Dr. Sc.

nav1304@ukr.net, ORCID: 0000-0003-4057-7085

Lebediev V.A., Dr.Ph

nevsdzer253@gmail.com, ORCID: 0000-0001-9563-621X

Melitopol School of Applied Geometry

Bogdan Khmelnitsky Melitopol State Pedagogical University (Ukraine)

Kravets O.V., Dr.Ph

oleg.kravets@tsatu.edu.ua, ORCID: 0000-0002-5643-0910

Dmytro Motornyi Tavria State Agrotechnological University (Ukraine)

One of the most scientific and complex purpose of engineering are the objects of gas turbine construction. In fact, many of problems solving in this brunch are the same as in the agricultural machinery, energy machines and complexes in their formulation.

Traditionally, the development and manufacture of gas turbine engines and compressors are the important directions for gas turbines. Due to the wide variety of compressors and their indicators (principle of action, basic design features, created pressure, performance, frequency of rotation, power consumption) are used in the extensive majority of coal, metallurgical, oil and gas, aviation, ship, transport and other industries and also in industrial complexes.

However, at the same time, the requirements of customers are increasingly rising to the quality of turbines production, their economic indicators, reduction of mass-scale characteristics and metal capacity, rising operational safety, environmental cleanliness in work, as well as repairability.

The reliability of gas turbine engines substantially depends on the reliability of compressor blades and turbines. This is due to the fact that in addition to stretching and bending from centrifugal forces, bending and torsion from a gas flow, the blades experience alternating stresses from vibration loads, the amplitude and frequency of which vary over a wide range. In addition, turbine and compressor blades are the most widespread, since more than 2000 pieces are spent on the manufacture of one GTE. shoulder blades. Therefore, improving their geometric shape is an important scientific and technical task, the solution of which is to use the achievements of the Applied Geometry and Computer Technology to model and visualize the bypasses of blade machines, and then to manufacture them at the high-speed processing centers with CNC. 
Key words: discrete interpolation, method of interpolation, angular parameters, compressor blade.

Formulation of the problem. One of the most scientific and complex purposes of mechanical engineering are the tasks of gas turbine construction [1.3]. Actually, the relevance of the tasks in this brunch is confirmed by many problems which solved in this industry are the same as in agricultural machinery, energy machines and complexes.

The reliability of gas turbine engines depends to a large extent on the reliability of the compressor blades (pic. 1) [2-3].

Due to the fact, that they are the most loaded details, in addition, because of the stretching and bending from centrifugal forces, bending and twisting from the gas flow, they experience variable voltages from the vibrational loads, amplitude and the frequency of which varies in wide limits. Besides, turbine and compressor blades are the most massive. Therefore, the improving of their geometric shape is the important scientific and technical task.

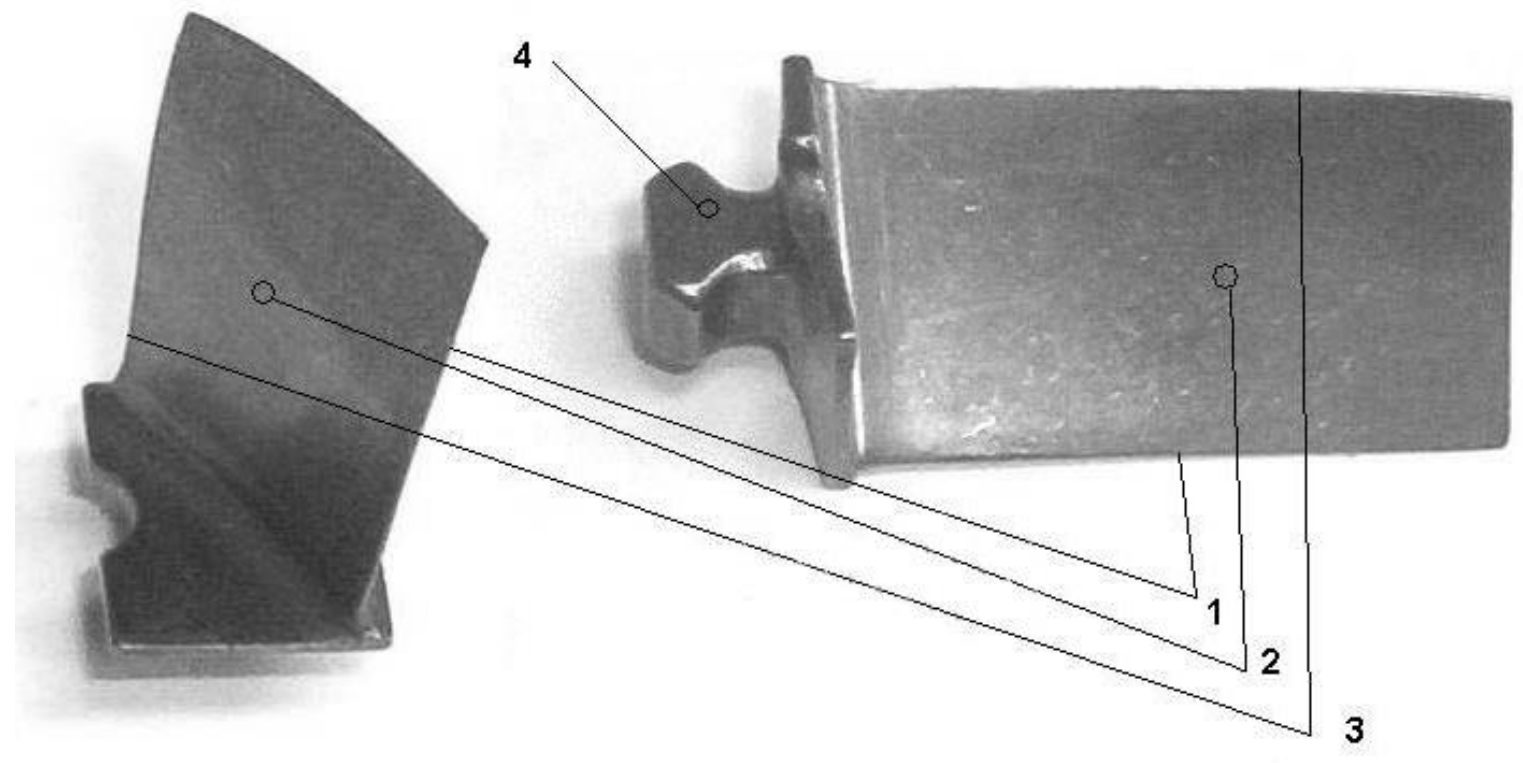

1 - front edge; 2 - blade pen; 3 - rear edge; 4 - lock of the blade

Pic.1. Compressor blade

Analysis of recent research and publications. One of the largest developers and manufacturer of the gas turbine engines for many sectors of the national economy, not only in Ukraine, but also abroad, is the state enterprise and scientific production of the gas turbine building complex "ZoryaMashproject", which, since 2004, has been used for processing the blanks of turbines blade and compressors by the Swiss firm Starraghert.

In this enterprise, the development of a geometrical model of the axial compressor blade is used as a method of the profiling technique, which is based on the distribution of the flowing part of a certain number of flat segments (pic.2) [4]. The specially prepared electronic document is formed through the consistent profiling of flat sections of the compressor blade, which contains the 
coordinates of the profile of the blade for the successive transfer to the processing center. The processing center forms a geometrical model of the treated compressor blade, based on the inputted data by its software.

When the flat sections of the airfoil of the compressor blade are profiling, the initial data are [5] the coordinates of the theoretical profile of the blade, describing the rear edge and trough, and setting by the discrete set of points, and also the coordinates of the centers and the radius of the circle arcs, describing the input and output edges of the profiles (pic. 3).
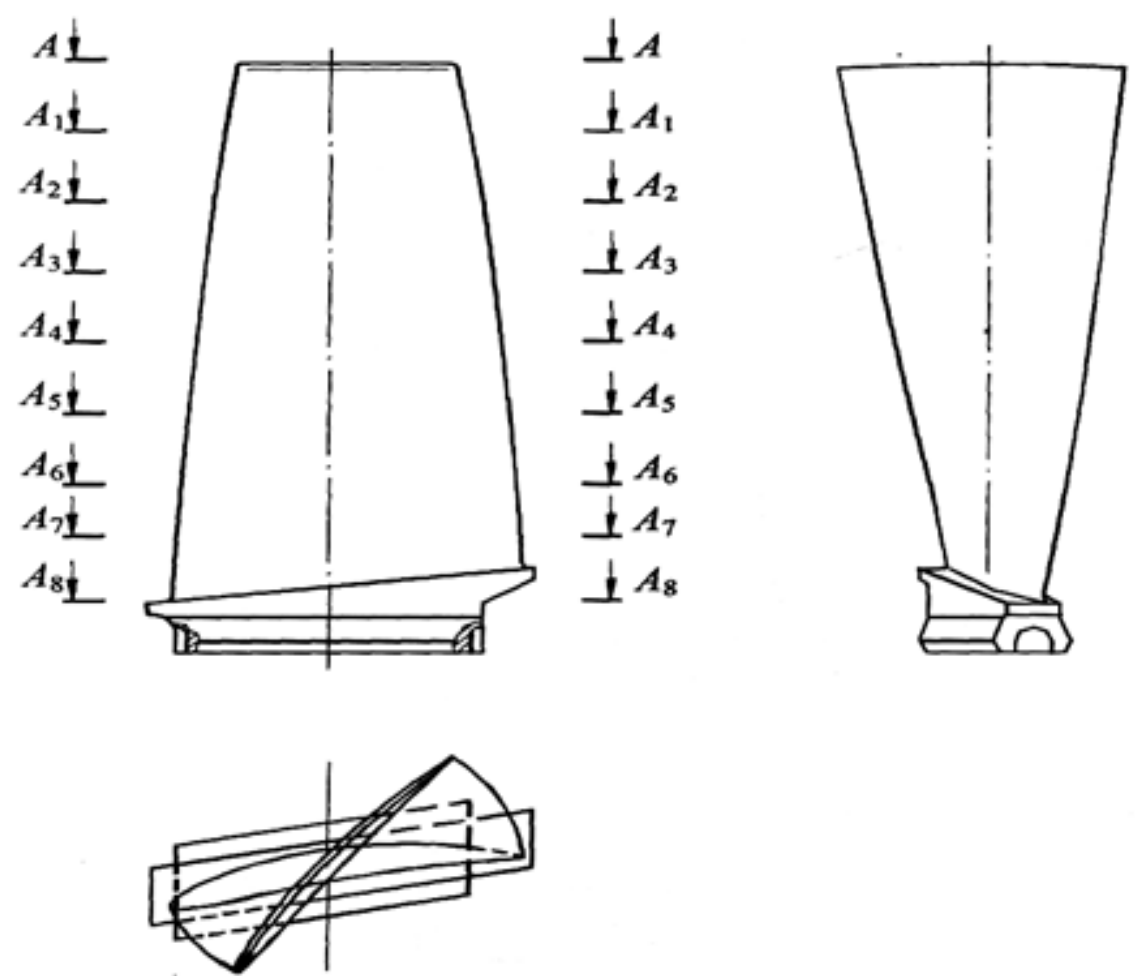

Pic.2. Method of profiling flat sections of the blade

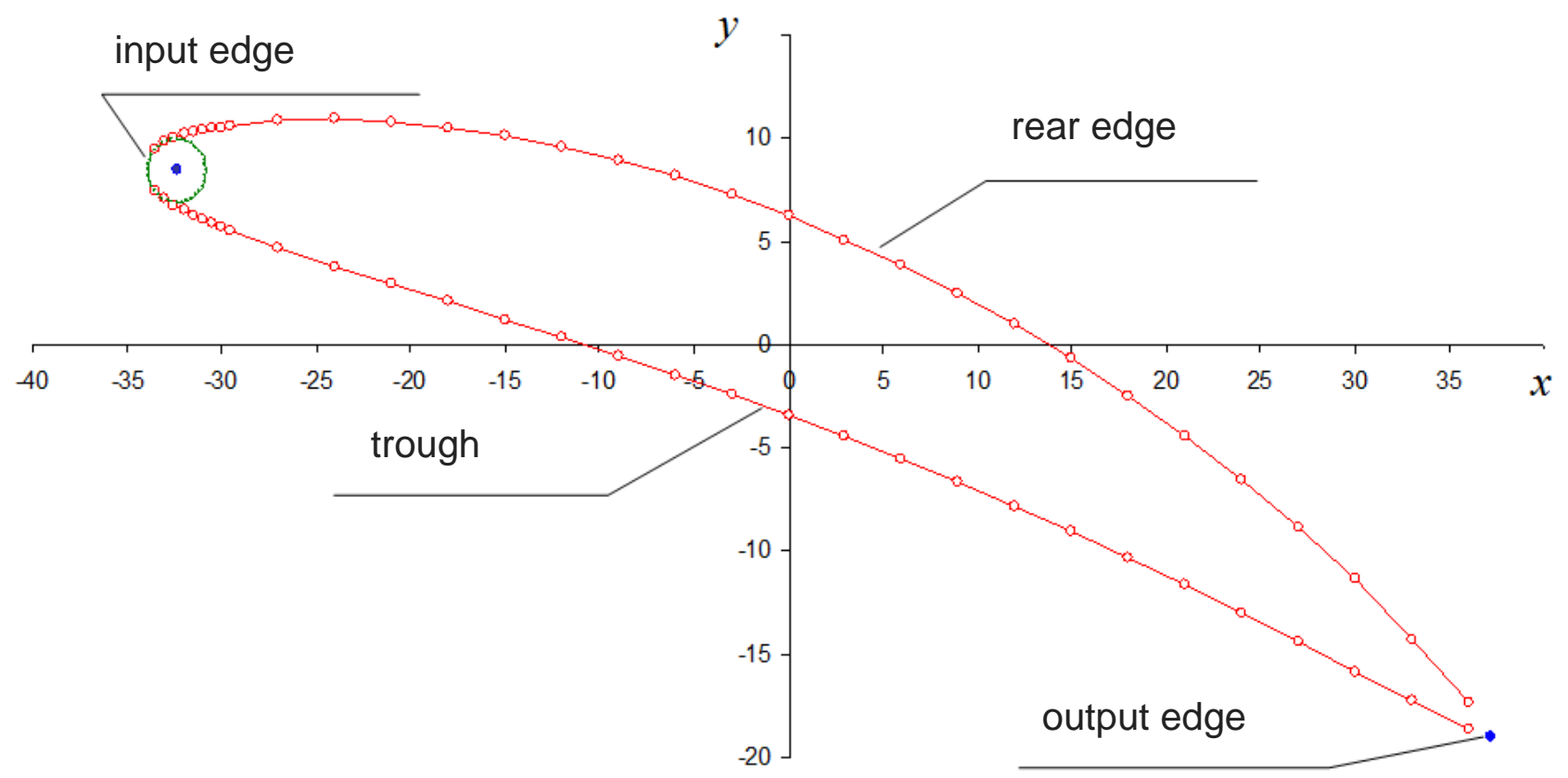

Pic.3. Section of the compressor blade profile 
It is known from the practice, that analyzing the initial data of the section profiles of the blade, there are points which clearly fall out of the smooth strokes of the rear edge or trough of the compressor blade (pic. 4). It is impossible to identify these points using the damn graphic documentation. These points are determined either by analyzing of the profiles of the blade (in the calculation of differential-geometric characteristics), or as a result of the enlargement of the geometrical model of the section of the blade on the PEC. In some cases, the existence of such points stems from the fact, that information about the coordinates of the bypass profiles of compressor blades is typed manually into the drawing and graphic documentation, which does not exclude gross errors.

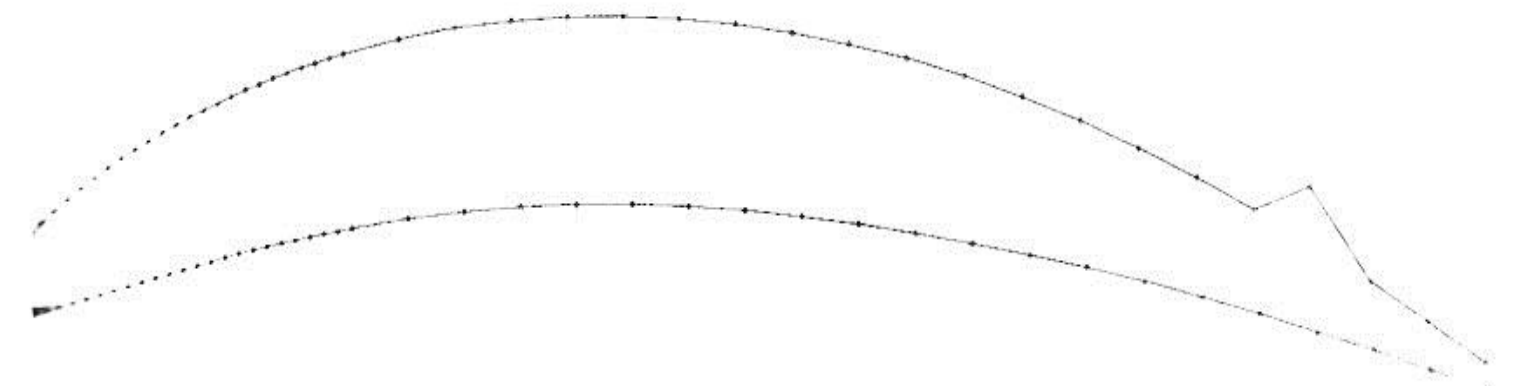

Pic.4. Profile of the blade with an incorrectly set point of the blade rear edge

In order to ensure, that the control program does not produce undesirable results in the process of making compressor blades on high-speed technological equipment, it is necessary to correct them, rather than to allow the processing of blades with such anomalies.

The main part. The main algorithm of the condensation method can be applied, when the rear edge and trough of sections of the blade profile are condensing; it is based on the variation formation of different schemes of angular parameters [8]. According to this algorithm, the geometric characteristics of the initial DRC (p. 1 of the main algorithm of the method) are determined, based on which the geometric features of the initial DRC are determined. As a result, the researching of differential-geometric characteristics of the theoretical profile [6] the abnormal points of blades can be identified and corrected. At the picture 5, there is a fragment of the trough of the theoretical profile of the blade of the axial type compressor, which contains the point $i$, clearly falling out of the smooth bypass of the profile trough. In order to correct the ordinate of this point was used the following technique:

Algorithm of the correction of the point.

1. Replacing links $(i-1, i)$ and $(i, i+1)$ conditional link $(i-1, i+1)$.

2. We calculate the values of intermediate angles of the adjacent $\gamma_{i-1}^{*}$ and $\gamma_{i+1}^{*}$ at appropriate points $i-1$ and $i+1$.

3. Taking into account the obtained angles $\gamma_{i-1}^{*}$ and $\gamma_{i+1}^{*}$ for conditional link $(i-1, i+1)$ define the clarified angle of the adjacent $\gamma_{i}^{y m}$ in $i$ point of the 
way $\gamma_{\text {opt }}[7]$ out of condition

$$
\gamma_{i}^{y m}=\frac{1}{2} \gamma_{o p t}^{0}, \text { where } \gamma_{o p t}^{0}=\left\{\begin{array}{l}
\min \left(\gamma_{i-1}^{*}, \gamma_{i}^{*}\right), \gamma_{i}^{0}<0, \\
(-1) \min \left(\left|\gamma_{i-1}^{*}\right|,\left|\gamma_{i}^{*}\right|\right), \gamma_{i}^{0}>0,
\end{array}\right.
$$

4. We may receive a refined ordinate $y_{i}^{y m}$ Expressions

- for the blade trough

$$
\begin{aligned}
& y_{i}^{y m}=\frac{1}{2 \operatorname{tg}\left(\pi-\gamma_{i}^{y m}\right)}\left(\operatorname{tg}\left(\pi-\gamma_{i}^{y m}\right) \cdot\left(y_{i-1}+y_{i+1}\right)+x_{i-1}-x_{i+1}\right)+ \\
& \frac{1}{2 \operatorname{tg}\left(\pi-\gamma_{i}^{y m}\right)} \sqrt{\left(x_{i-1}+x_{i+1}\right)^{2}+A_{i} \cdot \operatorname{tg}\left(\pi-\gamma_{i}^{y m}\right)},
\end{aligned}
$$

where the value of the coefficient $A_{i}$ is determined by the formula $A_{i}=y_{i-1} \cdot\left(y_{i-1} \cdot \operatorname{tg}\left(\pi-\gamma_{i}^{y m}\right)-2 y_{i+1} \cdot \operatorname{tg}\left(\pi-\gamma_{i}^{y m}\right)+2 x_{i-1}+2 x_{i+1}-4 x_{i}\right)+$

$+y_{i+1}\left(y_{i+1} \cdot \operatorname{tg}\left(\pi-\gamma_{i}^{y m}\right)-2\left(x_{i-1}+x_{i+1}\right)+4 x_{i}\right)+4 x_{i} \cdot \operatorname{tg}\left(\pi-\gamma_{i}^{y m}\right) \cdot\left(x_{i-1}+\right.$

$\left.x_{i+1}-x_{i}\right)-4 x_{i-1} \cdot x_{i+1} \cdot \operatorname{tg}\left(\pi-\gamma_{i}^{y m}\right)$;

- for the rear edge of the blade

$$
\begin{aligned}
& y_{i}^{y}=\frac{1}{2 \operatorname{tg}\left|\gamma_{i}^{y m}\right|}\left(\operatorname{tg}\left|\gamma_{i}^{y m}\right| \cdot\left(y_{i-1}+y_{i+1}\right)+x_{i-1}-x_{i+1}\right)+ \\
& \frac{1}{2 \operatorname{tg}\left|\gamma_{i}^{y m}\right|} \sqrt{\left(x_{i-1}+x_{i+1}\right)^{2}+A_{i} \cdot \operatorname{tg}\left|\gamma_{i}^{y m}\right|},
\end{aligned}
$$

where the value of the coefficient $A_{i}$ is determined by the formula

$$
\begin{aligned}
& A_{i}=y_{i-1} \cdot\left(y_{i-1} \cdot \operatorname{tg}\left|\gamma_{i}^{y m}\right|-2 y_{i+1} \cdot \operatorname{tg}\left|\gamma_{i}^{y m}\right|+2 x_{i-1}+2 x_{i+1}-4 x_{i}\right)+ \\
& +y_{i+1}\left(y_{i+1} \cdot \operatorname{tg}\left|\gamma_{i}^{y m}\right|-2\left(x_{i-1}+x_{i+1}\right)+4 x_{i}\right)+4 x_{i} \cdot \operatorname{tg}\left|\gamma_{i}^{y m}\right| \cdot\left(x_{i-1}+\right. \\
& \left.x_{i+1}-x_{i}\right)-4 x_{i-1} \cdot x_{i+1} \cdot \operatorname{tg}\left|\gamma_{i}^{y m}\right| .
\end{aligned}
$$

5. We accept the refined coordinates of the theoretical profile for the rear edge and trough of the blade as the initial ordinates of these points

$$
\begin{aligned}
& y_{i}^{0}=y_{i}^{y m} ; \\
& \gamma_{i}^{0}=\gamma_{i}^{y m} .
\end{aligned}
$$

After the correction of the ordinates of the similar points, which were identified as a result of the determination of differential-geometric characteristics of the rear edge and trough of the blade, we receive the refined coordinates of the theoretical profile of the blade.

Processing consistently the theoretical profiles of the blade, preparing for the process, the conclusion was made regarding the correctness of the task of the 
initial data. The obtained data is the initial information to set up the bypasses of the flat section of blades and then with its subsequent elaboration at the processing center.

In certain cases, during the processing of the detail, the tool can move along the trajectory slightly different from the given one at the time of the movement on elementary trajectories (straight, arcs, curves) between the reference points. However, you can set up such amount of the reference points, where the deviations from the actual trajectory will be less than the given value and the detail will be processed within the specified accuracy. Thus, the initial stage of the presentation of the trajectory of the detail is connected, moreover, in the receipt of coordinates of the reference points of the trajectory. This design phase is particularly important, because one of the important components of the machine's error are usually the geometric errors.

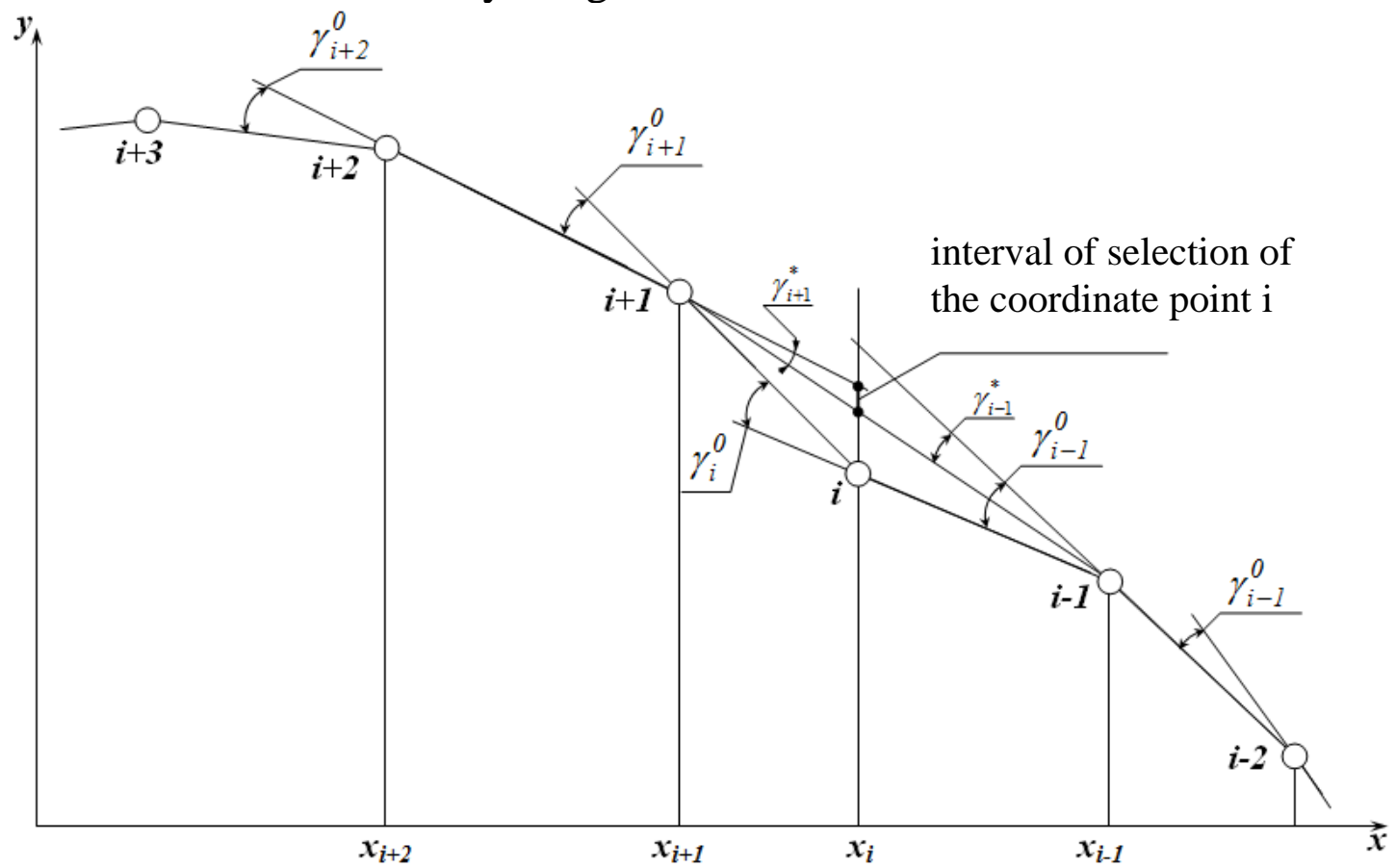

Pic. 5. Fragment of the profile of the blade with an incorrectly set point on the trough

In order to condensate the profiles contour of the flat sections of the blade, it is possible to apply the Method of Condensation which was developed by us and is based on the variative formation of different schemes of angular parameters. [8-10]. To the end of that, the coordinates of four additional points are added to the refined theoretical profile $B_{1}, B_{2}, 32_{c}, 32_{\kappa}$ the profile of the compressor blade (pic. 6 ), determined by us additionally.

$$
\begin{array}{ll}
x_{B_{1}}=x_{O_{1}}-R_{1} ; & x_{B_{2}}=x_{O_{2}}+R_{2} ; \\
y_{B_{1}}=y_{O_{1}} ; & y_{B_{2}}=y_{O_{2}},
\end{array}
$$

where $x_{O_{1}}, y_{O_{1}}, x_{O_{2}}, y_{O_{2}}$ - are coordinates of the input and output edges 
respectively in the global coordinate system $0 x y$.

$R_{1}, R_{2}$ - radius of the input and output edges, respectively.

The coordinates of the point $n$ rear edge and trough $\left(n_{C}\right.$ and $\left.n_{K}\right)$ define as tangents held from the last points of the backrest and trough profile $\left((n-1)_{c}\right.$ and $\left.(n-1)_{K}\right)$ to the circumference of the output edge. We will compare the numerical values of coordinates, applying the well-known methods of the Analytical Geometry, as a result of solving the system of equations (8) and (9)

$$
\begin{aligned}
& \left\{\begin{array}{l}
l_{(n-1)_{C}-n_{C}}=\sqrt{\left(x_{n_{C}}-x_{(n-1)_{C}}\right)^{2}+\left(y_{n_{C}}-y_{(n-1)_{C}}\right)^{2}} \\
R_{2}=\sqrt{\left(x_{n_{C}}-x_{O_{2}}\right)^{2}+\left(y_{n_{C}}-y_{O_{2}}\right)^{2}} ;
\end{array}\right. \\
& \left\{\begin{array}{l}
l_{(n-1)_{K}-n_{K}}=\sqrt{\left(x_{n_{K}}-x_{(n-1)_{K}}\right)^{2}+\left(y_{n_{K}}-y_{(n-1)_{K}}\right)^{2}} \\
R_{2}=\sqrt{\left(x_{n_{K}}-x_{O_{2}}\right)^{2}+\left(y_{n_{K}}-y_{O_{2}}\right)^{2}}
\end{array}\right.
\end{aligned}
$$

where $l_{(n-1)_{C}-n_{C}}, l_{(n-1)_{K}-n_{K}}$-is the length of links $\left((n-1)_{C}, n_{C}\right)$ and $\left((n-1)_{C}, n_{C}\right)$ accordingly

$$
\begin{aligned}
& l_{(n-1)_{C}-n_{C}}=\sqrt{l_{1}^{2}-R_{2}^{2}}=\sqrt{\left(x_{O_{2}}-x_{(n-1)_{C}}\right)^{2}+\left(y_{O_{2}}-y_{(n-1)_{C}}\right)^{2}-R_{2}^{2}} ; \\
& l_{(n-1)_{K}-n_{K}}=\sqrt{l_{2}^{2}-R_{2}^{2}}=\sqrt{\left(x_{O_{2}}-x_{(n-1)_{K}}\right)^{2}+\left(y_{O_{2}}-y_{(n-1)_{K}}\right)^{2}-R_{2}^{2}} .
\end{aligned}
$$

The points of the raw are renumbered and form a single profile, which is the initial data for condensation. After that, considering the peculiarities of the Geometry of the compressor blade profile, the condensation process of the obtained profile is under way, according to the main method of the algorithm.
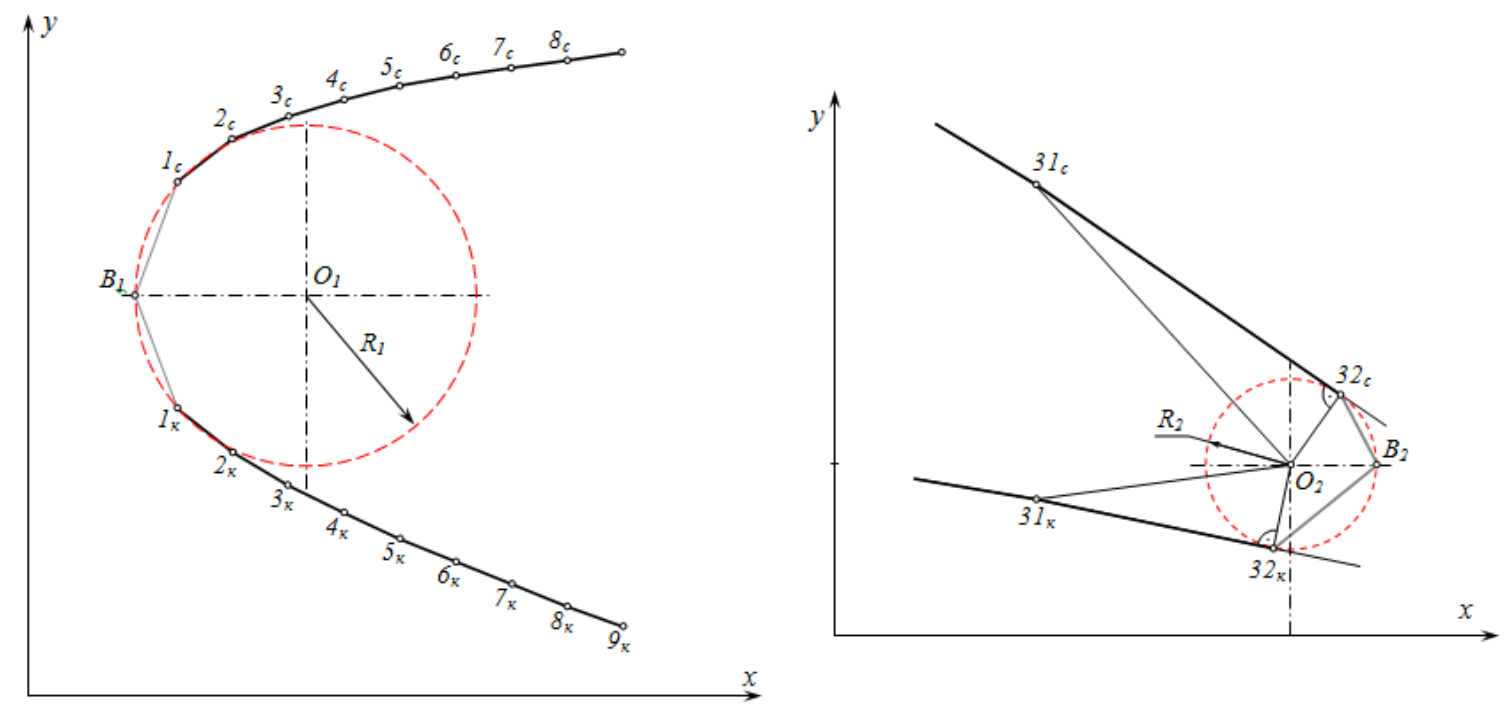

Pic. 6. Fragments of the input and output edges of the profile of the compressor blade 
There is the fragment of the comparative analysis of the profile of one of the compressor blade segments near the output edge at the pic.7, which was calculated according to the proposed and traditional method. As it can be clear from the schemes, the difference between localized ordinates in the obtained points of condensation and the contour is calculated according to the traditional method, complies with the acceptable standards (no more $(0.012 \mathrm{~mm})$ ).
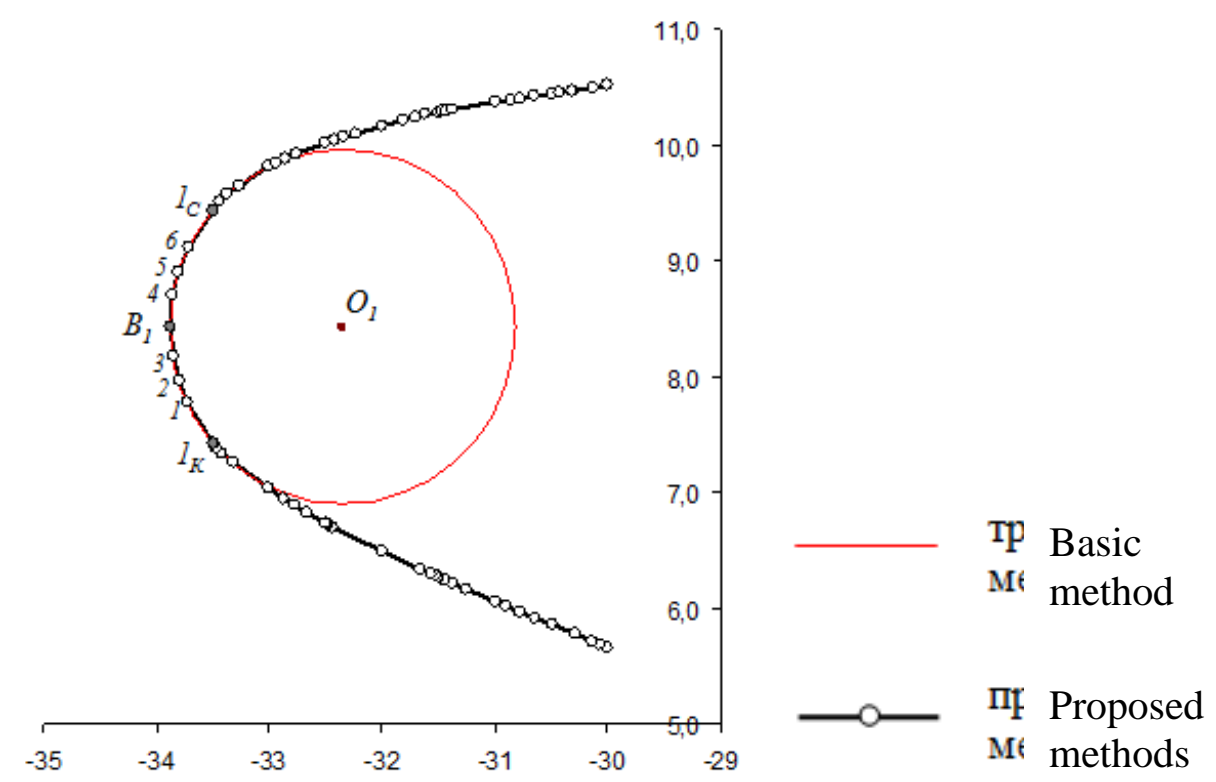

Pic 7. Comparative analysis

Table 1

Comparative analysis of basic and proposed methods

\begin{tabular}{|c|c|c|c|c|c|c|}
\hline \multirow{2}{*}{ № point } & \multicolumn{2}{|c|}{ Basic method } & \multicolumn{2}{c|}{ Proposed methods } & \multicolumn{2}{c|}{ Difference } \\
\cline { 2 - 7 } & $\mathrm{X}$ & $\mathrm{Y}$ & $\mathrm{X}$ & $\mathrm{Y}$ & $\Delta, \mathrm{MM}$ & $\%$ \\
\hline $1_{\mathrm{K}}$ & $-33,500436$ & 7,426000 & $-33,500000$ & 7,426000 & $-0,000436$ & $0,0013 \%$ \\
\hline 1 & $-33,735490$ & 7,787417 & $-33,723476$ & 7,787417 & $-0,012014$ & $0,0356 \%$ \\
\hline 2 & $-33,805278$ & 7,966064 & $-33,796698$ & 7,966064 & $-0,008580$ & $0,0253 \%$ \\
\hline 3 & $-33,856983$ & 8,179360 & $-33,850989$ & 8,179360 & $-0,005995$ & $0,0177 \%$ \\
\hline $\mathrm{B}_{1}$ & $-33,878000$ & 8,432000 & $-33,878000$ & 8,432000 & 0,000000 & $0,0000 \%$ \\
\hline 4 & $-33,852518$ & 8,709984 & $-33,855181$ & 8,709984 & 0,002663 & $-0,0079 \%$ \\
\hline 5 & $-33,801173$ & 8,910575 & $-33,809349$ & 8,910575 & 0,008176 & $-0,0242 \%$ \\
\hline 6 & $-33,718263$ & 9,112412 & $-33,709701$ & 9,112412 & $-0,008561$ & $0,0254 \%$ \\
\hline $1_{\mathrm{c}}$ & $-33,499562$ & 9,439000 & $-33,500000$ & 9,439000 & 0,000438 & $-0,0013 \%$ \\
\hline
\end{tabular}

\section{Conclusion.}

Coming to conclusions, it can be said, that the advantages of the proposed technique are following:

- It gives the ability step-by-step to carry out the condensation of the profile of the blade.

- There is no oscillation in the nodes.

- It gives the ability to control the shape of the simulated curve.

- Excluding the procedure of the bypasses. 
- It has simple algorithmic implementation and, as a result, there is a reduction in computational error.

- The final profile satisfies the given design requirements.

To sum up, the obtained coordinates of the profiles of the flat section of the blades are initial information for the graphic editor of Unigraphics, in which a solid-state model of the compressor blade is formed. After the control examination of the blade in the system of Unigraphics, data is transferred directly to the processing center's software complex NX-154 Starrage.

\section{Literature}

1. Веннерстром А. Высоконапорные осевые компрессоры: история разработки и дальнейшее развитие. Современное машиностроение. 1991. Cep. А. №3. С. 98-112.

2. Кампсти Н. Аэродинамика компрессоров [пер. с англ.]. М.: Мир, 2000. $688 \mathrm{c.}$

3. Ржавин Ю.А. Осевые и центробежные компрессоры двигателей летательных аппаратов: теория, конструкция и расчёт. М.: МАИ, 1995. $343 \mathrm{c}$.

4. Спицин В.С. Геометричне моделювання компресорних лопаткових апаратів: дисс. ... к-та. техн. наук: 05.01.01 Миколаїв, Національний університет кораблебудування ім. адмірала Макарова, 2005. 204 с.

5. Фокс А., Пратт М. Вычислительная геометрия. Применение в проектировании и на производстве: Пер. с англ. М.: Мир, 1982. 304 с., ил.

6. Найдиш А.В., Балюба І.Г., Верещага В.М., Спірінцев Д.В.. Варіативне дискретне геометричне моделювання. Сучасні проблеми моделювання. Мелітополь, 2018. Вып.11. С. 108-114.

7. Найдиш В.М., Спірінцев Д.В. Варіативна схема згущення ДПК на основі кутових параметрів 3 використанням додаткових умов. Пращуi ТДАТУ. Мелітополь: ТДАТУ, 2007. Вип.4. Т.35. С.3-9.

8. Найдыш А.В., Спиринцев Д.В. Основной алгоритм метода сгущения на основе вариативного формирования разностных схем угловых параметров. Сборник докладов XVIII Юбилейной международной научно-практической конференции «Научные итоги: достижения, проекты, гипотезы». Выпуск 18. Минеральные Воды, 2013. С. 147-150.

9. Спірінцев Д.В. Формування різницевої схеми згущення ДПК на основі кутових параметрів. Прикладна геометрія та інженерна графіка. Київ: Вип. 81. 2008.

10.Спірінцев Д.В. Варіативне формування різницевих схем згущення ДПК на основі кутових параметрів. Праці / Таврійська державна агротехнічна академія. Мелітополь: ТДАТА, 2008. Вип.36. С.34-37. 


\title{
ЗАСТОСУВАННЯ МЕТОДУ ВАРІАТИВНОГО ФОРМУВАННЯ РІЗНИЦЕВИХ СХЕМ КУТОВИХ ПАРАМЕТРІВ ДЛЯ МОДЕЛЮВАННЯ ПРОФІЛЮ ПЛОСКИХ ПЕРЕРІЗІВ ПЕРА ЛОПАТКИ КОМПРЕССОРА
}

\author{
Спірінцев Д.В., Найдиш А.В., Лебедєв В.О., Кравець О.В.
}

Одним з найбільш наукоємних $i$ складних призначень машинобудування є об'єкти газотурбінного будівництва. Насправді, багато проблем, щяо вирімуються в иіій галузі, по свойй постановичі аналогічні завданням сельхозмашинобудівництва, енергетичних машин $i$ комплексів.

Традищійно важливим напрямком для газотурбінобудування $\epsilon$ розробка і виготовлення газотурбінних двигунів $i$ компресорів. Завдяки широкому розмаїттю компресорів та їх показників (принщип дї, основні конструктивні особливості, створюваний тиск, продуктивність, частота обертання, енергоспоживання) вони використовуються в переважній більшості вугільних, металургійних, нафтогазових, авіаиійних, суднових, транспортній та інших галузях, а також у промислових комплексах.

Однак, водночас вимоги замовників дедалі більше зростають до якості виробництва турбін, їх економічних показників, зменшення масових характеристик та металоємності, підвищення експлуатаційної безпеки, екологічної чистоти в роботі, а також ремонтопридатності.

Надійність газотурбінних двигунів істотно залежить від надійності лопаток компресора та турбін. Це пов'язано з тим, що крім розтягування та згинання від відиентрових сил, згинання та кручення від потоку газу, лопаті відчувають змінні напруження від вібраційних навантажень, амплітуда та частота яких змінюються в широкому діапазоні. Крім того, лопатки турбіни та компресора $є$ найбільш розповсюдженими, оскільки на виготовлення одного ГТД витрачається понад 2000 штук лопаток. Тому вдосконалення їх геометричної форми $\epsilon$ важливим науково-технічним завданням, вирішенням якого $\epsilon$ використання досягнень прикладної геометрії та комп'ютерних технологій для моделювання та візуалізачії обводів лопаткових апаратів, а потім їх виготовлення на високошвидкісних обробних центрах з ЧПУ.

Ключові слова: дискретна інтерполяція, метод згущення, кутові параметри, лопатка компресора. 


\title{
ПРИМЕНЕНИЕ МЕТОДА ВАРИАТИВНОГО ФОРМИРОВАНИЯ РАЗНОСТНЫХ СХЕМ УГЛОВЫХ ПАРАМЕТРОВ ДЛЯ МОДЕЛИРОВАНИЯ ПРОФИЛЯ ПЛОСКИХ СЕЧЕНИЯ ПЕРА ЛОПАТКИ КОМПРЕССОРА
}

\author{
Спиринцев Д.В., Найдыш А.В., Лебедев В.А., Кравец О.В.
}

Одной из наиболее наукоёмких и сложных задач машиностроения являются задачи газотурбиностроения. Многие задачи, решаемые в данной отрасли по своей постановке аналогичны задачам сельхозмашиностороения, энергетических машин и комплексов.

Традииионно важным направлением для газотурбиностроения является разработка и изготовление газотурбинных двигателей $и$ компрессоров. Благодаря широкому разнообразию компрессоров $u$ ux показателям (принцип действия, основные конструктивные особенности, создаваемое давление, производительность, частота вращения, потребляемая мощность) компрессоры находят свое применение на подавляющем большинстве предприятий угольной, металлургической, нефтегазовой, авиационной, корабельной, автотранспортной и других отраслях, а также в производственных комплексах.

Однако, в то же время требования заказчиков все больше растут к качеству производства турбин, их экономических показателей, уменьшение массовых характеристик и металлоемкости, повышения эксплуатационной безопасности, экологической чистоты в работе, а также ремонтопригодности.

Надежность газотурбинных двигателей существенно зависит от надежности лопаток компрессора и турбин. Это связано с тем, что кроме растяжения и изгиба от иентробежных сил, изгиба и кручения от газового потока испытывают переменные напряжения от вибрационных нагрузок, амплитуда и частота которых изменяются в широких пределах. $K$ тому же турбинные и компрессорные лопатки являются наиболее массовыми, поскольку на изготовление одного ГТД затрачивается более 2000 шт. лопаток. Поэтому совершенствование их геометрической формы является важным научно-техническим заданием, решением которого является использование достижений прикладной геометрии и компьютерных технологий для моделирования и визуализаџии обводов лопаточных аппаратов, а затем их изготовления на высокоскоростных обрабатываюших иентрах с ЧПУ.

Ключевые слова: дискретная интерполяиия, метод сгущения, угловые параметры, лопатка компрессора.

\section{Refereces}

1. Vennerstrom A. (1991) High-pressure axial compressors: the history of development and further development. Sovremennoe mashinostroenie, 3, 98-112. [in Russian] 
2. Kampsti N. (2000) The aerodynamics of compressors. M.: Mir, 688 [in Rusiian]

3. Rzhavin YU.A. (1995) Axial and centrifugal compressors of aircraft engines: theory, design and calculation. M.: MAI, 343 [in Russian]

4. Spicin V.C. (2005) Geometric modeling of compressor blade machines: candidate's thesis: 05.01.01. Mikolaïv, Nacional'nij universitet korablebuduvannya im. admirala Makarova, [in Ukrainian]

5. Foks, A., Pratt, M. (1982) Computational geometry. Application in design and manufacturing. M.: Mir, [in Russian]

6. Najdish, A.V., Balyuba, I.G., Vereshchaga, V.M., Spirincev, D.V. (2018) Variational discrete geometric modeling. Suchasni problemi modelyuvannya. Melitopol',11, 108-114. [in Ukrainian]

7. Najdish, V.M., Spirincev, D.V. (2007) Variative diagram of thickening of DPK on the basis of angular parameters using additional conditions. Praci TDATU. Melitopol, 4, 35, 3-9. [in Ukrainian]

8. Najdysh, A.V., Spirincev, D.V. (2013) The main algorithm of the condensation method based on the variative formation of divergent circuits of angular parameters. Sbornik dokladov XVIII YUbilejnoj mezhdunarodnoj nauchno-prakticheskoj konferencii «Nauchnye itogi: dostizheniya, proekty, gipotezy». Mineral'nye Vody, 18, 147-150. [in Russian]

9. Spirincev, D.V. (2008) Formation of the difference scheme of thickening of the DPK on the basis of angular parameters. Prikladna geometriya ta inzhenerna grafika. Kiïv, 81, [in Ukrainian]

10. Spirincev, D.V. (2008) Variative formation of difference DPK thickening schemes based on angular parameters. Praci Tavrijs'ka derzhavna agrotekhnichna akademiya. Melitopol': TDATA, 36, 34-37. [in Ukrainian] 